\title{
Effect of incorporating orange maize flour into beef sausage and its associated quality attributes
}

\begin{abstract}
Arthur Vera', Newlove A. Afoakwah ${ }^{*}$
A b s t r a c t: The aim of this study was to incorporate different percentages $(0 \%, 10 \%, 20 \%, 30 \%$, and $50 \%)$ of orange maize flour (OMF) into beef sausage, and to study the bioactive qualities of the OMF. Also, the physicochemical, microbiological and sensory characteristics of the OMF beef sausages were explored. Results from the bioactive analyses of the OMF indicated it had total carotenoid content of $14.31 \mu \mathrm{g} / \mathrm{g}$, while the tannin content was $1.52 \mathrm{mg} / \mathrm{g}$. The moisture content of the beef sausages decreased when $O M F$ levels in the sausages were increased. The fat contents of the OMF beef sausages were significantly lower $(p<0.05)$ than that of the control, while the emulsion stability of the $30 \%$ OMF beef sausage was not statistically different to that of the control sausages. The iodine values of the OMF beef sausages tended to increase with an increased content of OMF. Salmonella spp. and Staphylococcus aureus were not detected in the sausages. Escherichia coli detected were within the range of 1.0 to $2.0 \mathrm{CFU} / \mathrm{g}$. A consumer preference study showed the most acceptable sausage among the OMF beef sausages contained 20\% OMF. This study showed that OMF has the potential to be used as a fat replacer, can maintain the sensory properties of beef sausages and prevent or limit microbial growth on beef sausages formulated with added OMF.
\end{abstract}

Keywords: orange maize flour, bioactive, total carotenoid, iodine value, fat replacer.

\section{Introduction}

Orange maize $(\mathrm{OM})$ is a new crop that is bio-fortified with vitamin A. This crop is a staple food that provides substantial amounts of energy, vi$\operatorname{tamin} \mathrm{A}$, antioxidants (carotene, xanthophylls, polyphenols), and vitamins C, E, and D (Alamu et al., 2014). It is widely grown commercially in

Zambia, Nigeria, Zimbabwe, Tanzania and Ghana (Alamu et al., 2015; Pixley et al., 2013; Smale et al., 2015; Hwang et al., 2015). The polyphenols and the carotenoids present in OM flour (OMF) are known to be antioxidants, which play a vital functions as anti-carcinogenic, antioxidant, antiviral, antimicrobial, and anti-inflammatory molecules. The potency of this bio-fortified maize is to enhance vitamin A status in children (Gannon et al., 2014; Palmer et al., 2016). The presence of vitamins $\mathrm{C}$ and $\mathrm{K}$, $\beta$-carotene and selenium in OMF could improve the functions of the human thyroid gland and immune system (Shah et al., 2016).

Maize is used to produce products including corn flour, cornstarch, corn gluten, corn syrup, tortillas, tortilla chips, polenta cornmeal, corn oil, popcorn, and cornflakes, but the usage of $\mathrm{OM}$ in food production is limited, despite its nutritional attributes. However, the intake of OM-based products could contribute to phenolic acid ingestion (Alamu, 2014) and other vital nutrients.

Thus, consumption of sausage with incorporated OMF could improve the vitamin A status in children, pregnant woman and lactating mothers and could provide the potential to scavenge generated free radicals, prevent protein energy malnutrition, reduce the risks of coronary heart disease, tumour incidence, and cancer, decrease blood cholesterol level and fat absorption and could have the potential to lower blood pressure (Jo et al., 2015). Also, vitamin A is noted to play a very key role in good vision and cell differentiation, and therefore, OMF intake could prevent vitamin A deficiency that can result in blindness, increased child and maternal mortality, immune system function impairment and abnormal foetal development (WHO, 2009).

In this paper, some bioactive qualities of OMF, and the physicochemical properties, the sensory attributes and the microbiological quality of sausages with incorporated OMF were studied.

${ }^{1}$ Department of Food Science and Technology University for Development Studies, P.O. Box 1882, Tamale, Ghana

*Corresponding author: Newlove A. Afoakwah, nafoakwah@uds.edu.gh 


\section{Materials and methods}

The solar dried OM was provided by the Department of Food Science and Technology, University for Development Studies, Tamale, Ghana. Adobo, white pepper, black pepper, chilli pepper, polyphosphate, iodised salt and purified water were purchased from a supermarket in Tamale, the northern region of Ghana. Lean meat (boneless beef) used for the sausage was obtained from the meat unit of the Animal Science Department, University for Development Studies. The boneless beef was acquired from a healthy adult cow slaughtered based on the approved code of ethics for slaughtering animals in Ghana. The lean meat was trimmed of subcutaneous fat and of connective tissues. The meat was stored in a refrigerator at $4 \pm 1^{\circ} \mathrm{C}$ for about $6-8 \mathrm{~h}$ and frozen at $-18^{\circ} \mathrm{C}$ until it was processed.

\section{Orange maize flour preparation}

Five (5) kilograms of solar dried OM was milled into flour using a plate mill (Quaker City Grinding Co, Model 4-E, Phoenixville, PA, USA). It was then sieved through a $0.2 \mathrm{~mm}$ screen. The OMF obtained was kept in a container with fitted lid and was stored at room temperature until it was utilised.

\section{Determination of bioactive compounds in solar dried OMF}

\section{Carotenoid extraction and its total content}

To determine the total content of carotenoids, the method described by Lucia et al. (2012) was employed. In brief, $5 \mathrm{~g}$ of the OMF was weighed using a digital balance (Bel Engineering, model MA0434/05). The carotenoid was extracted by continuously adding $15 \mathrm{~mL}$ of acetone until a paste was obtained. This was transferred into a sintered-funnel $(5 \mu \mathrm{m})$, which was fixed to a $150 \mathrm{~mL}$ Buchner flask. This was filtered under vacuum. This technique was repeated three times. The extract acquired was conveyed to a $200 \mathrm{~mL}$ sieve funnel containing $20 \mathrm{~mL}$ petroleum ether. The acetone removal was conducted by adding slowly ultrapure-water (Milli-Q-Millipore). The extract was then conveyed through a funnel to a $50 \mathrm{~mL}$ volumetric flask containing $10 \mathrm{~g}$ of anhydrous sodium sulphate. The volume was made up using petroleum ether, and the absorbance was read at $450 \mathrm{~nm}$. The total carotenoid content was calculated using the following equation:
Caroteniod content $\left(\mu \frac{\mathrm{g}}{\mathrm{g}}\right)=\frac{\mathrm{A} \times \mathrm{V}(\mathrm{mL}) \times 10^{4}}{\lambda_{1 \mathrm{~cm} \times \mathrm{Z}(\mathrm{g})}^{1 \%}}$

Where: $\mathrm{A}=$ absorbance; $\mathrm{V}=$ total extract volume; $Z=$ sample weight; $\quad \lambda_{1 \mathrm{~cm}}^{1 \%}=2592(\beta$-carotene extinction coefficient in petroleum ether).

\section{Determination of ascorbic acid}

Ascorbic acid was determined using the dyestuff titration method, which was expatiated according to $A O A C$ (2006). OMF (5 g) was digested with oxalic acid $(0.4 \mathrm{~g} / 100 \mathrm{~g})$. The aliquot was titrated against dyestuff that was formerly standardised using ascorbic acid solution. The ascorbic acid content was calculated using the following equation.

Vitamin C $(\mathrm{mg} / 100 \mathrm{~g})=$ titre value $\times 0.606 \times \frac{100}{\begin{array}{c}\text { weight of } \\ \text { sample }\end{array}}$

\section{Determination of phytic acid content}

The phytic acid content of the OMF was determined using the method of Alamu et al. (2014), wherein the atomic ratio of 4:6 Fe:P was used to calculate the phytic acid content.

\section{Determination of tannin content}

Tannin content determination was carried out using the $A O A C$ (2006) method. OMF (5 g) was added to $50 \mathrm{~mL}$ of distilled water and agitated. The mixture was held for $30 \mathrm{~min}$ at room temperature and was filtered using Whatman no. 4 grade filter paper. The extract $(2 \mathrm{~mL})$ was put into a $50 \mathrm{~mL}$ volumetric flask. Similarly, $2 \mathrm{~mL}$ standard tannic solution $(0.1 \mathrm{mg} / \mathrm{mL}$ tannic acid) and $2 \mathrm{~mL}$ distilled water were put in separate volumetric flasks and used as standards. A saturated sodium carbonate $\left(\mathrm{Na}_{2} \mathrm{CO}_{3} ; 2.5 \mathrm{~mL}\right)$ solution and Folin-C $(1 \mathrm{~mL})$ reagent were added to a separate flask and volume was made up to $50 \mathrm{~mL}$ and vortexed. Afterward $1.5 \mathrm{~h}$, the OMF was filtered using Whatman no. 4 grade filter paper. The absorbance was read at $760 \mathrm{~nm}$ against a reagent blank. Tannin was calculated according to equation (2) and is expressed as $\mathrm{mg}$ of tannic acid equivalence (TAE) per $100 \mathrm{~g}$.

$$
\text { Tanin }=\frac{(\text { standard concentration } \times \text { sample absorbance })}{(\text { standard absorbance } \times \text { weight of sample })}
$$




\section{Sausage preparation and processing}

An adapted method of Afoakwah et al. (2015) with modification was employed for the preparation of the OMF beef sausages. Before the sausages were prepared, the lean meat and fat were stored at $-18^{\circ} \mathrm{C}$. A mixture of lean meat, fat, salt, ice, adobo, white pepper, black pepper, chilli pepper, polyphosphate, and water was considered as a control (OMF $0 \%)$. Different quantities $(10 \%, 20 \%, 30 \%$ and $50 \%$ ) of OMF, adobo, white pepper, black pepper, chilli pepper, polyphosphate, were added to the sausage, which constituted the experimental groups. The preparation of the ingredient mixtures using the correct ratio of fat and lean meat and different concentrations of OMF was carried out with caution. The mixture was minced at an emulsion temperature of $10^{\circ} \mathrm{C}$ for $10 \mathrm{~min}$. The raw sausage emulsion was stuffed into cellulose casing using a sausage stuffer. Then, the sausages were tied manually into $10-13 \mathrm{~cm}$ lengths that were weighed and smoked for $45 \mathrm{~min}$ at $70^{\circ} \mathrm{C}$ in an electric sausage smoker. The sausages were kept in a refrigerator at $4{ }^{\circ} \mathrm{C}$.

\section{Component analyses of the sausages}

\section{Moisture determination}

The moisture content in the sausages was determined using $A O A C$ (2006). In brief, $5 \mathrm{~g}$ of sausage sample was transferred into a previously dried and weighed dish. The dish was placed in an oven thermostatically controlled at $105^{\circ} \mathrm{C}$ for $5 \mathrm{~h}$ until a constant weight was obtained. The sausage sample was again weighed after cooling in a desiccator. The percentage of moisture was then calculated using the equation:

Moisture $=\frac{(\text { weight of wet sample } \times \text { weight of dry sample })}{\text { weight of wet sample }} \times 100[\%](3)$

\section{Protein determination}

Protein content of the sausages was determined by employing the Kjeldahl method with KELPLUS nitrogen estimation system employing the method of $A O A C$ (2006). Sausage ( $2 \mathrm{~g}$ ) was placed into the digestion flask. A selenium tablet utilised as Kjeldahl catalyst was added to the sausage sample. Concentrated sulphuric acid $(10 \mathrm{~mL})$ was mixed with the sample and was fixed to the digester for $8 \mathrm{~h}$ until the solution obtained was clear. The cooled digest was placed into a $100 \mathrm{~mL}$ volumetric flask and made up to the mark with distilled water. The distillation apparatus was set and rinsed for $10 \mathrm{~min}$ after boiling. Twenty-five millilitres $(25 \mathrm{~mL})$ of $2 \%$ boric acid was pipetted into a conical flask. Five (5) drops of methyl red were added to the flask as an indicator and the sample was diluted with $75 \mathrm{~mL}$ distilled water. The digest $(10 \mathrm{~mL})$ was made alkaline with $20 \mathrm{~mL}$ of $40 \% \mathrm{NaOH}$ and distilled. The steam exit of the distillation apparatus was closed and the change of colour of the boric acid solution to green was timed. The mixture was distilled for $15 \mathrm{~min}$. The filtrate was then titrated against $0.1 \mathrm{~N}$ $\mathrm{HCl}$. The percentage total was calculated:

Protein $=\%$ nitrogen $\times$ conversion factor $(6.25)[\%]$

\section{Crude fat determination}

Using the $A O A C$ (2006) method, the fat content of the sausages was estimated using Soxhlet extraction apparatus. In brief, a previously dried (air oven at $\left.100^{\circ} \mathrm{C}\right) 250 \mathrm{~mL}$ round bottom flask was weighed accurately. About $5.0 \mathrm{~g}$ of sausage sample was weighed on to a $22 \times 80 \mathrm{~mm}$ paper thimble. About $150 \mathrm{~mL}$ of petroleum spirit B.P. $40-60^{\circ} \mathrm{C}$ was added to the round bottom flask and the apparatus assembled. The Soxhlet extractor with a condenser connected was refluxed for $6 \mathrm{~h}$ on a heating mantle. After extraction, the thimble was removed and the solvent recovered by distillation. The flask and fat/oil were then heated in an oven at about $103^{\circ} \mathrm{C}$ to evaporate the solvent. The flask and contents were then transferred into a desiccator to cool. They were then weighed, the values recorded and the $\%$ fat was calculated according to equation (5).

$$
\text { Fat }=\frac{\mathrm{W}_{4}-\mathrm{W}_{3}}{\mathrm{~W}_{2}-\mathrm{W}_{1}} \times 100[\%]
$$

Where: $\mathrm{W}_{1}=$ weight of oven dried thimble, $\mathrm{W}_{2}=$ weight of bottom flask with sample, $\mathrm{W}_{3}=$ weight of round bottom flask, $\mathrm{W}_{4}=$ weight of round bottom flask with fat.

\section{Ash determination}

Ash content in the sausages was estimated by employing the $A O A C$ (2006) method. In brief, $5 \mathrm{~g}$ of dried sausage was placed in a weighed crucible and ignited until no charred particles remained in the crucible. The crucible was put in muffle furnace for $2 \mathrm{~h}$ at $600^{\circ} \mathrm{C}$ until a white ash was obtained. Thereafter, the crucible was cooled in a desiccator and reweighed. The percent ash was calculated using equation (6)

$$
\text { Ash }=\frac{\text { Weight of ash }}{\text { Weight of sample }} \times 100[\%]
$$




\section{Total carbohydrate determination}

The total carbohydrate in the sausages was determined by the differential method, and this was achieved by subtracting percent amounts of crude protein, crude fat, moisture, fiber and ash from $100 \%$.

Carbohydrate $=100-[\%]($ protein + fat + fiber + ash $+\underset{\text { content }}{\text { coisture }})$

\section{Determination of $\mathrm{pH}$}

Using ISO 2917 (2004) method, the pH of the sausages were measured using Crison $\mathrm{pH}$ meter. Prior to the $\mathrm{pH}$ reading, the $\mathrm{pH}$ meter was standardised using a buffer solution of $\mathrm{pH}=7.02$ and 4.00 to $20^{\circ} \mathrm{C}$. In brief, $5 \mathrm{~g}$ sausage sample was homogenised with $20 \mathrm{~mL}$ distilled water for $10-15 \mathrm{~s}$. The $\mathrm{pH}$ meter electrodes were inserted into the slurry, and the $\mathrm{pH}$ values recorded in triplicate.

\section{Functional properties of the sausages}

\section{Water holding capacity}

Employing the method of Maltin et al. (2003), empty containers used for this test were labelled and weighed. The sausage samples were pierced all around with a needle and were hung on a stick in the container. The new weight (weight of sample and container together) was measured and recorded, then the samples were kept in a desiccator for $24 \mathrm{~h}$ at room temperature. The samples were then placed in a bag and hung in an airtight container using a hook under the lid. After the required storage time, i.e. $24 \mathrm{~h}$ at room temperature, samples were weighed again. The water holding capacity (WHC) was calculated using equation (8):

$$
\mathrm{WHC} \%=\frac{\mathrm{T} 3-\mathrm{T} 2}{\mathrm{~T} 3-\mathrm{T} 1} \times 100 \%
$$

Where: T1 is weight of empty container, T2 is weight of container and drained liquid, T3 is weight of container and whole sample.

\section{Emulsion stability}

The emulsion stability was measured according to the modified method as described by Jitngarmkusol et al. (2008). In brief, $1 \mathrm{~g}$ of each sample was dispersed in $16 \mathrm{~mL}$ of distilled water contained in falcon tube. The mixture was homogenised for $30 \mathrm{~s}$. Approximately $2 \mathrm{~mL}$ of petroleum ether was added, and the mixture was homogenised again for $30 \mathrm{~s}$. Each emulsified sample was transferred into a centrifuge tube, heated in a water bath at $85^{\circ} \mathrm{C}$ for $15 \mathrm{~min}$, cooled down to room temperature, and centrifuged at $1100 \mathrm{~g}$ for $5 \mathrm{~min}$.

The emulsion stability (ES) was calculated using the equation:

$$
\text { Emulsion Stability }=\frac{\mathrm{V}_{3}}{\mathrm{~V}_{1}} \times 100[\%]
$$

Where; $V_{1}$ is the volume of emulsion before centrifugation, $\mathrm{V}_{3}$ is the volume of the remaining emulsified layer after centrifugation.

\section{Determination of the iodine value of the sausages}

The iodine value was determined by extracting fat from the sausage samples using the Soxhlet method. The fat obtained after extraction was kept in an oven to dry. After cooling in a desiccator, fats were transferred into centrifuge tubes. About $1 \mathrm{~g}$ of each fat sample was weighed into conical flasks. Approximately $10 \mathrm{~mL}$ of chloroform was added and mixed. Hanus iodine solution $(25 \mathrm{~mL})$ was added with a pipette. The mixture in the flask was kept in the dark for $30 \mathrm{mins}$. About $10 \mathrm{~mL}$ potassium iodide solution and $100 \mathrm{~mL}$ distilled water was added and was the flask was shaken. The iodine liberated in the process was titrated with $0.1 \mathrm{~N}$ sodium thiosulfate solution. The flask was stoppered and shaken vigorously while titrating until a pale-yellow colour was obtained. Exactly $2 \mathrm{~mL}$ of $0.5 \%$ starch solution was used and titration was continued until the blue color disappeared. Blank titration was also performed. The entire test was performed in triplicate. Iodine values were calculated according to equation (10).

Iodine value $=\frac{(\mathrm{B}-\mathrm{S}) \times \mathrm{N} \text { of } \mathrm{NaS}_{2} \mathrm{O}_{3} \times 0.127}{\text { Weight of sample }} \times 100[\%]$

Where $\mathrm{B}=$ blank titre, $\mathrm{S}=$ sample titre and $\mathrm{N}=$ normality of $\mathrm{NaS}_{2} \mathrm{O}_{3}-0.1 \mathrm{~N}$

\section{Microbiological analyses}

The microbial analysis of the sausages was performed using the method as described by Philip et al. (2002). Briefly, $25 \mathrm{~g}$ of sausage was placed in $225 \mathrm{~mL}$ buffered peptone water (Merck, Darmstadt, Germany) and homogenised in a stomacher for 2 min. The homogenate $(1 \mathrm{~mL})$ was pipetted into 9 $\mathrm{mL}$ of buffered peptone water to obtain a tenfold dilution. The solution was further step-wise diluted up to $10^{-5}$ dilution. The spread plate method was 
used to plate $0.5 \mathrm{~mL}$ of the 5 dilution levels. Total Plate Count Agar (Oxoid) was used for total aerobic plate count determination. Some microorganisms were isolated and identified from this agar. Salmonella-Shigella Agar (Oxoid) was used for Salmonella enumeration, Baird Parker Agar (Oxoid) was used for Staphylococcus aureus and MacConkey Agar (Oxoid) was used for Escherichia coli detection. Agar plates for Salmonella and total aerobic plate count was incubated at $37^{\circ} \mathrm{C}$. Baird Parker Agar plates for $S$. aureus were incubated at $35^{\circ} \mathrm{C}$, while MacConkey Agar plates for E. coli were incubated at $44.5^{\circ} \mathrm{C}$. In all, the incubation period was $24 \mathrm{~h}$, after which, suspect colonies of Salmonella, Shigella, and E. coli were identified prior to counting the colonies. Suspected Salmonella colonies on Salmonella-Shigella agar plates were recognised as light pink with dark/black centres and Shigella were colourless, black colonies were suspect $S$. aureus on Baird Parker agar plates, while pink colonies of E. coli were observed on the MacConkey agar plates. The citrate test was used as a confirmatory test for the suspect $E$. coli even though it is a common test for Salmonella and Shigella as well. In this test, Simmons citrate (Oxoid) agar plates was prepared according to the manufacturer's instructions and all suspected E. coli colonies transferred aseptically with further incubation at $37^{\circ} \mathrm{C}$ for 24 $\mathrm{h}$, after which, results were observed and recorded. Simmons citrate agar after preparation looked green; Salmonella, if positive in the citrate test, can change the colour to blue, whereas E. coli does not change the colour of the medium. For $S$. aureus, the use of Baird parker together with its supplement (rabbit plasma fibrinogen) was enough and, hence, no further test was needed.

\section{Sensory analysis of the sausages}

Sensory analysis was conducted using 50 untrained panellists. Panellists were asked to indicate how much they liked or disliked each of the sausages. Quality attributes (colour, texture, flavour, taste) and overall acceptability were scored based on five-point hedonic scale (1=dislike extremely, $2=$ dislike moderately, $3=$ neither like nor dislike $4=$ like moderately $5=$ like extremely). All sausages were prepared by grilling for about 10 mins. Sausage pieces $(1.5 \mathrm{~cm}$ long) were wrapped in aluminium foil and different samples were kept in separate plastic bags in an ice chest. They were then served to the panellists with three digit codes on disposable plates in a randomised order for evaluation.
Panellists were asked to rinse their mouth with water between tasting samples.

\section{Statistical analysis}

One-way ANOVA was performed to determine differences in characterisation parameters of the sausages with different levels of OMF incorporated. Minitab was used for the analysis of proximate data, XLSTAT-2016 for sensory data and SPSS version 17.0 for microbial data analysis. The significance was determined using the Tukey's pairwise comparison at $\mathrm{p}<0.05$.

\section{Results and discussion}

\section{Bioactive qualities of the bio-fortified orange maize flour}

The total carotenoid in the bio-fortified OMF was $14.31 \pm 0.3 \mu \mathrm{g} / \mathrm{g}$. From a comparative point of view, the values found in this study were higher than those reported for the conventionally bred bio-fortified orange maize varieties $(6-9 \mu \mathrm{g} / \mathrm{g})$ of vac and for white maize $(2 \mu \mathrm{g} / \mathrm{g})$ (Pixley et al., 2013). In this study, ascorbic acid was not detected in the OMF. This could be attributed to the drying method employed, which probably degraded it. Also, it could be attributed to the fact that ascorbic acid is sensitive to heat treatment, and so processing the OMF could have contributed to the ascorbic acid loss (Odriozola-Serrano et al., 2007).

The OMF contained tannin $(1.52 \pm 0.5 \mathrm{mg} / \mathrm{g})$. The concentration of tannins greatly varies among different cultivars, as well as among plants belonging to the same cultivar, and values of $0.8-70 \mathrm{mg} / \mathrm{g}$, expressed as catechin equivalent, have been reported by McMillan et al. (2007), so the amount of tannin in the OMF used in the current study is in this range (McMillan et al., 2007). However, the total content of tannin observed in this study is difficult to compare with the total tannin contents of other plants found in the literature, because methods of analysis, maturity stage of the plants, the type of plant cultivars and the plant part used for analysis can be different (Mamta and Shashi, 2015). Besides, tannins are a diverse group of compounds present in foods at variable levels. Hence, their consumption is virtually universal. Also, differences at the chemical level among the different tannins have resulted in diverse methods for measuring their concentrations. This could be why it is problematic to quantify the consumption levels of these compounds among dissimilar populations. The effect of food tannins on health is a public health issue (Mamta and Shashi, 
2015), although tannins have prophylactic effects, noted to be cardio-protective, anti-inflammatory, anti-carcinogenic and anti-mutagenic, amongst others. These attributes may be due to their free radical scavenging abilities and the potential to activate antioxidant enzymes (Mamta and Shashi, 2015).

A relatively low content of phytic acid was determined in the OMF $(6.34 \pm 0.6 \mathrm{mg} / 100 \mathrm{~g})$. Phytic acid is the primary phosphorus storage compound in cereals, legumes, nuts and oil seeds, and it accounts for up to $90 \%$ of the total phosphorous content, contributing as much as $1.5 \%$ of seed dry weight (Lan and Lott et al., 2005). This suggests that the phytate in the flour has the potential to increase the bio-accessibility and bioavailability of minerals and proteins. However, phytates should be $25 \mathrm{mg}$ or $<100 \mathrm{~g}$ (Onomi et al., 2004). The phytate content in the current research was in close agreement with Khan et al. (1991) and Nawab Khan and Manzoor (2006), who indicated a decreased concentration of phytic acid during heat treatment. Shahidi and Naczk (1995) showed that polyphenols are not distributed evenly in plant tissues; hence, fractional food processing can lead to loss or enrichment of some phenolic compounds.

\section{Proximate Composition of the Sausage}

As depicted in Table 1, the moisture contents of the sausages were significantly different $(p<0.05)$, and ranged between 61 to $67 \%$. As the percentage of OMF incorporated increased, the moisture content decreased $(\mathrm{p}<0.05)$. This might be as a result of OMF's ability, due to its fibre content, to hold most of the water as bound water (Choi et al., 2009). A similar result for moisture was reported by Afoakwah et al. (2015). Additionally, the fat contents of the OMF beef sausages (Table 1) were lower $(\mathrm{P}<0.05)$ than the control $(18.04 \pm 2.13)$ beef sausages. This was expected since the control sausages were formulated with a higher percentage of fat. Tobin et al. (2012) obtained similar results in their study where sausages prepared with high-fat levels had a higher fat content.

The ash content in the sausages showed a gradual increase as the OMF concentration increased. A significant difference $(\mathrm{p}<0.05)$ between the control beef sausage and the 50\% OMF and 30\% OMF beef sausages was observed. The increasing value for the ash content detected in the OMF incorporated sausages indicates the increasing mineral content in the sausages, which confirms that OMF is a rich source of mineral elements that are vital for biological functions in humans (Ullah et al., 2010; Nascimento et al., 2014).

The protein content in the OMF sausages increased as the content of OMF increased (Table 1). The protein results obtained were higher than those recorded by Méndez-Zamora et al. (2015) who used inulin and pectin in low-fat frankfurter sausages. OMF, which contains a higher quantity of carbohydrate, resulted in increasing carbohydrate content as the OMF content increased. Quinoa flour led to an increase in carbohydrate content and a decrease in moisture in sausages that were prepared with tilapia fillet waste (Zapata and de la Pava, 2018).

\section{pH of the Sausages}

As the amount of OMF in the sausages increased, the sausage pHs also increased (Figure 1). Sausage containing 50\% OMF had a significantly higher $\mathrm{pH}$ of 6.03 than did 10\% OMF sausage or control sausage, the $\mathrm{pH}$ of which was $5.93(\mathrm{p}<0.05)$.

Table 1. Proximate composition of beef sausages with added orange maize flour $(\mathrm{g} / 100 \mathrm{~g})$ and statistical differences

\begin{tabular}{lccccc}
\hline $\begin{array}{l}\text { Type of } \\
\text { Sausage }\end{array}$ & $\begin{array}{c}\text { Moisture } \\
\text { Content }\end{array}$ & Fat Content & Ash Content & $\begin{array}{c}\text { Protein } \\
\text { Content }\end{array}$ & $\begin{array}{c}\text { Carbohydrate } \\
\text { Content }\end{array}$ \\
\hline Control & $66.77 \pm 1.81^{\mathrm{a}}$ & $18.04 \pm 2.1^{\mathrm{aa}}$ & $1.49 \pm 0.26^{\mathrm{b}}$ & $12.34 \pm 1.26$ & $1.36 \pm 0.63^{\mathrm{b}}$ \\
OMF 10\% & $66.52 \pm 0.88^{\mathrm{a}}$ & $16.94 \pm 1.25^{\mathrm{ab}}$ & $1.57 \pm 0.10^{\mathrm{b}}$ & $12.28 \pm 0.10$ & $2.69 \pm 1.53^{\mathrm{ab}}$ \\
OMF 20\% & $63.72 \pm 0.08^{\mathrm{ab}}$ & $14.97 \pm 2.13^{\mathrm{ab}}$ & $1.95 \pm 0.17^{\mathrm{ab}}$ & $13.46 \pm 2.03$ & $5.90 \pm 2.68^{\mathrm{ab}}$ \\
OMF 30\% & $63.69 \pm 1.42^{\mathrm{ab}}$ & $12.41 \pm 1.57^{\mathrm{ab}}$ & $2.23 \pm 0.00^{\mathrm{a}}$ & $15.50 \pm 2.88$ & $6.17 \pm 0.10^{\mathrm{ab}}$ \\
OMF 50\% & $61.03 \pm 1.17^{\mathrm{b}}$ & $11.21 \pm 2.30^{\mathrm{b}}$ & $2.25 \pm 0.10^{\mathrm{a}}$ & $16.68 \pm 0.23$ & $8.83 \pm 2.00^{\mathrm{a}}$ \\
p value & 0.024 & 0.037 & 0.010 & 0.165 & 0.042 \\
\hline
\end{tabular}

Legend: Means with the same superscript letters in the same column are not significantly different at $\mathrm{P}<0.05$; OMF: orange maize flour. 


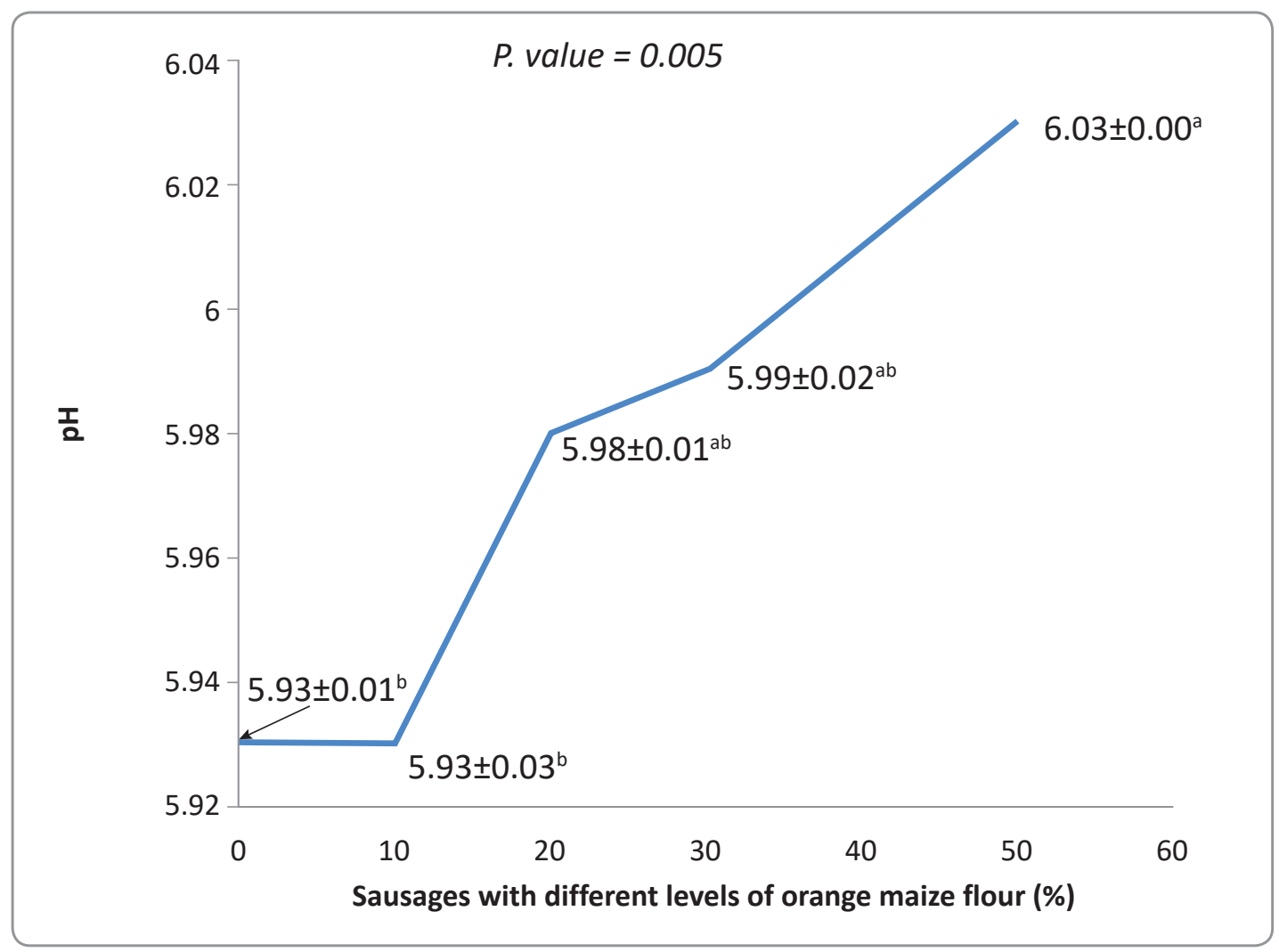

Figure 1. pH of sausages with different levels of incorporated orange maize flour.

In comparison to the results obtained by Choi et al. (2009), higher $\mathrm{pH}$ (6.47) was observed in sausages formulated with rice bran fibre, which was attributed to the effect of the minerals, such as iron, phosphorus, and calcium, present in the fibre. Higher $\mathrm{pH}$ values according to Kristinsson and Hultin (2003) are desirable for better water holding capacity, juiciness and other sensory parameters of sausages.

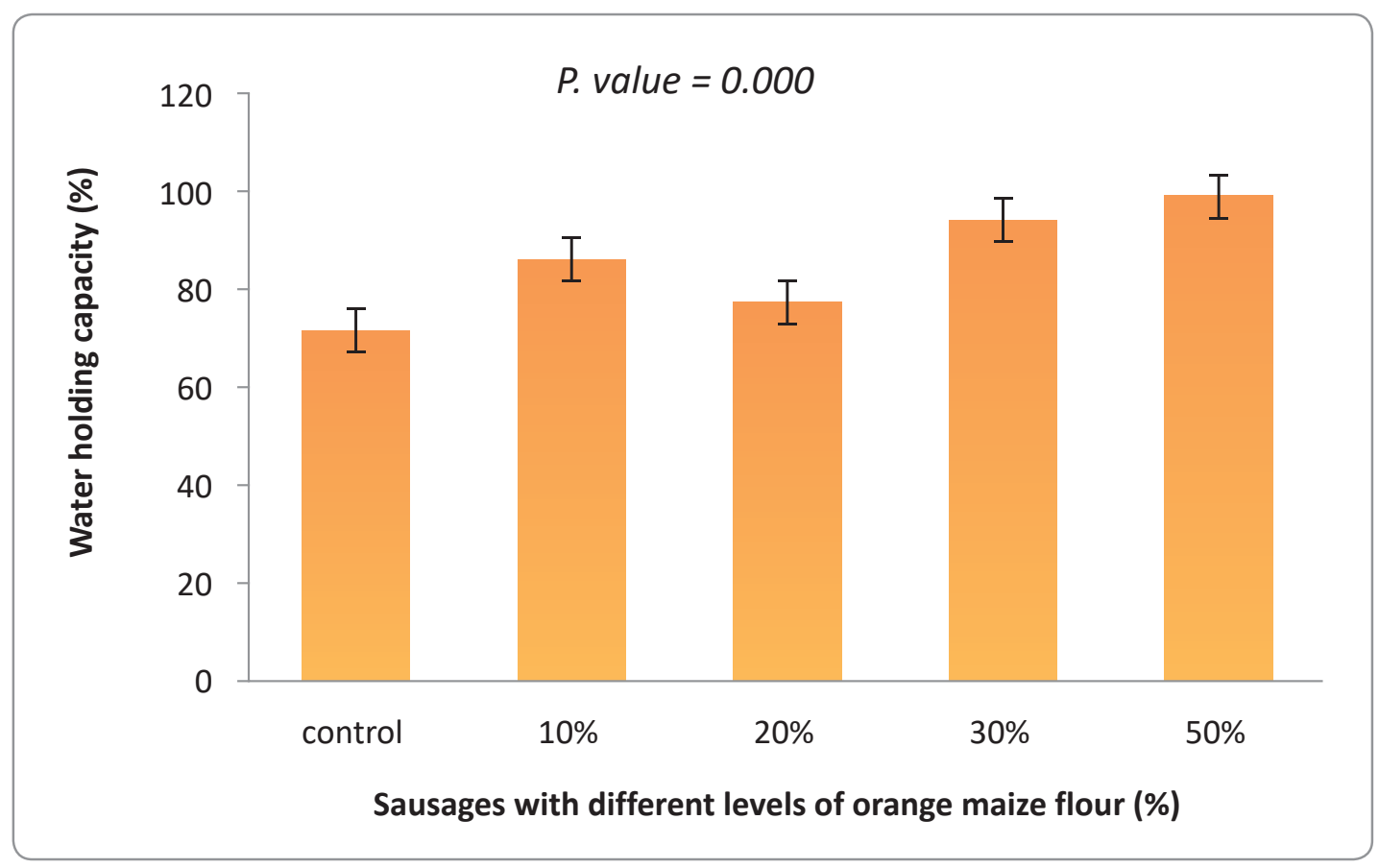

Figure 2. Water holding capacity of sausages with different levels of incorporated orange maize flour. 


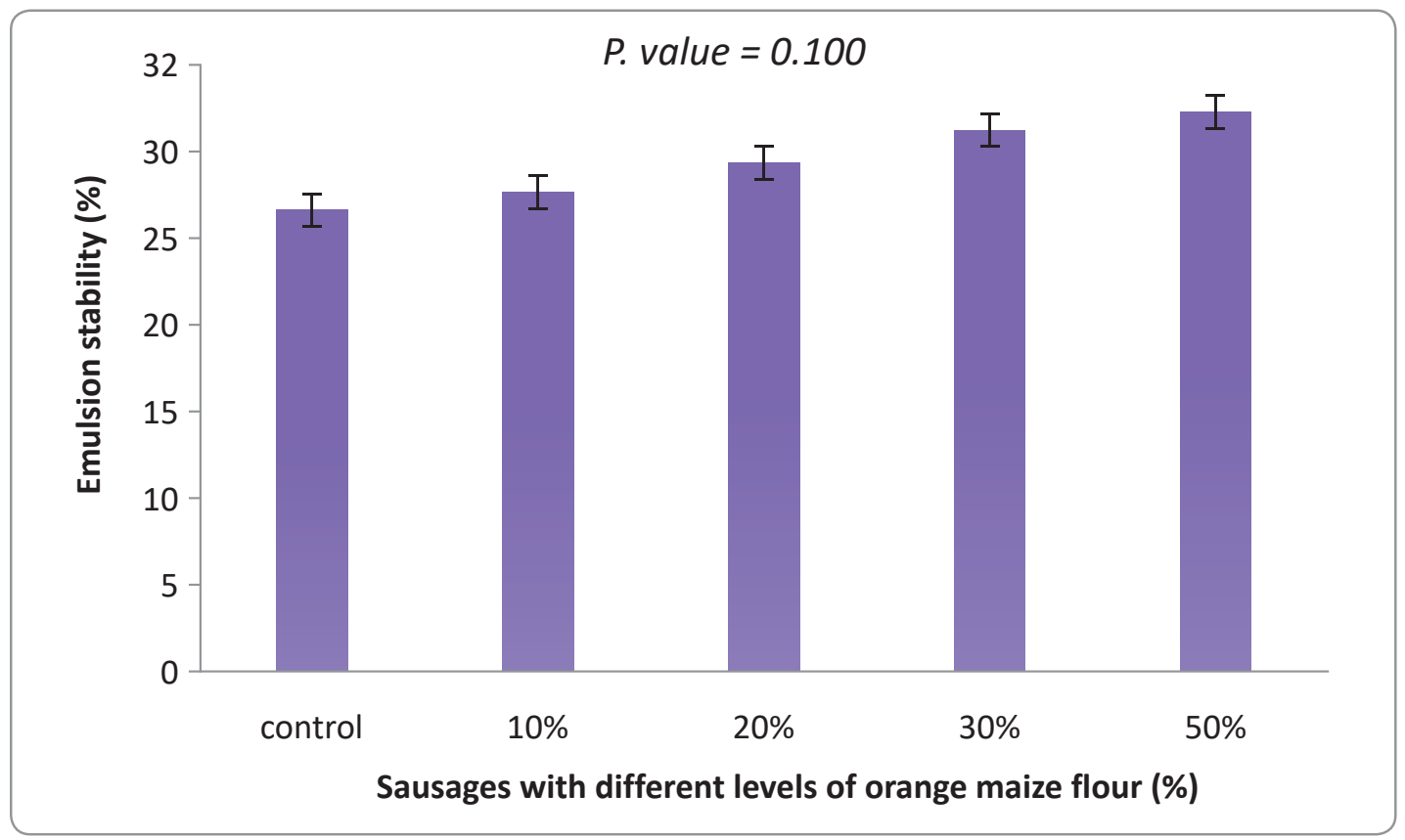

Figure 3. Emulsion stability of sausages with different levels of incorporated orange maize flour.

\section{Water holding capacity of the sausages}

Control sausages had the lowest WHC, while the $50 \%$ OMF sausages had a significantly higher WHC (Figure 2). This indicates that OMF has good WHC. However, the $20 \%$ OMF sausage had lower WHC than that of $10 \%$ OMF sausage. Serdaroglu and Degirmencioglu (2004) showed that corn flour ( $2 \%$ and $4 \%$ level) increased moisture retention in treated meat balls. Also, the increase in WHC caused by the OMF proves OMF has a good ability to form gel (Rodriguez-Furlan et al., 2014; Petersson et al., 2014). This could probably make OMF a suitable candidate for incorporation into sausages. WHC is the ability of meat to retain its water or added water during the use of external forces like cutting, heating, grinding or pressing (Judge et al., 1990). WHC is a significant indicator of dietary fibre, suggesting the inclusion of fibre in food product formulation (Petersson et al., 2014).

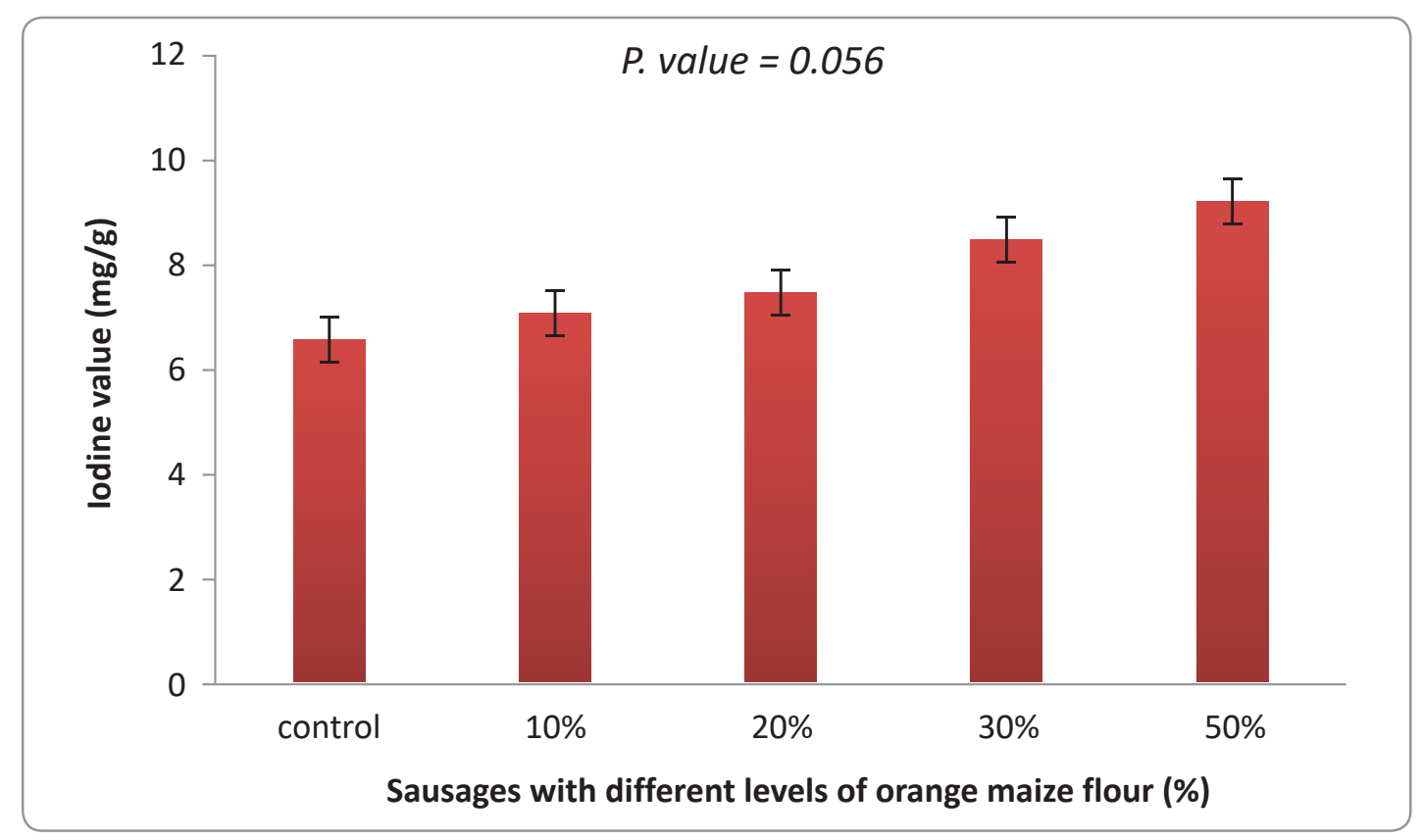

Figure 4. Iodine values of sausages with different levels of incorporated orange maize flour. 


\section{Emulsion stability of the sausages}

As shown in Figure 3, the emulsion stability, an indicator of unseparated fat and water retained by meat proteins upon heat processing, increased with increasing OMF content in the sausages. However as reported by Alvarez and Barbut (2013), a reduction in fat content of meat products leads to a drop in emulsion stability, because fat is needed to stabilise batters. However, in our study, the emulsion stabilities of the OMF beef sausages were comparable with the high fat control sausages, since no significant difference was observed $(\mathrm{p}<0.05)$. This suggests that OMF exhibited a fat-like property and also acted as an emulsifier.

\section{Iodine value of the sausages}

Iodine value was determined (Figure 4) to estimate the unsaturation level of the fat present in the formulated sausage products. The results indicated the unsaturation level improved with the increased addition of OMF, although there was no significant difference between the sausages $(p<0.05)$. This result confirms the fact that maize contains oil, which is rich in poly- and monounsaturated fatty acids (CRA, 2006). This rise in the unsaturated fat could make the product more desirable for consumption since unsaturated fat is considered as a healthy dietary fat.

\section{Microbiological quality of the formulated sausages}

As shown in Table 2, the effects of OMF in the sausages stored at $4^{\circ} \mathrm{C}$ were studied on days 0,4 , 8 and 12 to determine its microbiological qualities. Furthermore, the presence of E. coli, Salmonella spp. and $S$. aureus was determined. On day 0 and on day 4 of storage, there were no detectable bacteria in any of the sausages. However, on day 8, a total plate count of $11.50 \mathrm{CFU} / \mathrm{g}$ and $5.00 \mathrm{CFU} / \mathrm{g}$ were observed for the control and 10\% OMF sausages

Table 2. Microbiological quality (CFU/g) of the sausages.

\begin{tabular}{|c|c|c|c|c|}
\hline \multirow{2}{*}{ Sausage } & \multicolumn{4}{|c|}{ Day of Storage } \\
\hline & Day 0 & Day 4 & Day 8 & Day 12 \\
\hline \multicolumn{5}{|c|}{ Total Plate Count } \\
\hline Control & nd & nd & $11.50 \pm 2.12^{\mathrm{a}}$ & $21.00 \pm 2.83^{\mathrm{b}}$ \\
\hline OMF $10 \%$ & nd & nd & $5.00 \pm 2.83^{\mathrm{c}}$ & $18.50 \pm 2.12^{\mathrm{d}}$ \\
\hline OMF $20 \%$ & nd & nd & nd & $14.50 \pm 7.78^{\mathrm{e}}$ \\
\hline OMF $30 \%$ & nd & nd & nd & $7.50 \pm 2.12^{\mathrm{f}}$ \\
\hline OMF $50 \%$ & nd & nd & nd & $7.50 \pm 0.71^{\mathrm{f}}$ \\
\hline \multicolumn{5}{|c|}{ Salmonella spp. } \\
\hline Control & nd & nd & nd & nd \\
\hline OMF $10 \%$ & nd & nd & nd & nd \\
\hline OMF $20 \%$ & nd & nd & nd & nd \\
\hline OMF $30 \%$ & nd & nd & nd & nd \\
\hline OMF $50 \%$ & nd & nd & nd & nd \\
\hline \multicolumn{5}{|l|}{ E. coli } \\
\hline Control & nd & nd & $1.00 \pm 0.00^{\mathrm{a}}$ & $3.50 \pm 2.12^{b}$ \\
\hline OMF $10 \%$ & nd & nd & $1.00 \pm 0.00^{\mathrm{a}}$ & $2.00 \pm 1.01^{\mathrm{a}}$ \\
\hline OMF $20 \%$ & nd & nd & nd & $1.00 \pm 1.41 \mathrm{~b}^{\mathrm{a}}$ \\
\hline OMF $30 \%$ & nd & nd & nd & $1.50 \pm 0.71^{\mathrm{c}}$ \\
\hline OMF $50 \%$ & nd & nd & nd & $2.00 \pm 0.00^{\mathrm{a}}$ \\
\hline \multicolumn{5}{|c|}{ Staphylococcus aureus } \\
\hline Control & nd & nd & nd & nd \\
\hline OMF $10 \%$ & nd & nd & nd & nd \\
\hline OMF $20 \%$ & nd & nd & nd & nd \\
\hline OMF $30 \%$ & nd & nd & nd & nd \\
\hline OMF $50 \%$ & nd & nd & nd & nd \\
\hline
\end{tabular}

Legend: Means with the same superscript letters in the same column are not significantly different at $\mathrm{P}<0.05$; OMF: orange maize flour; nd: not detected; OMF: orange maize flour 
Table 3. Mean ranks of sensory properties of sausages and statistical differences.

\begin{tabular}{lccccc}
\hline Treatment & Colour & Texture & Flavour & Taste & Overall Acceptability \\
\hline Control & 114.00 & $133.11 \mathrm{ab}$ & $126.32 \mathrm{abc}$ & $144.47 \mathrm{~b}$ & $129.16 \mathrm{ab}$ \\
OMF 10\% & 133.58 & $130.56 \mathrm{ab}$ & $152.82 \mathrm{c}$ & $142.71 \mathrm{~b}$ & $101.17 \mathrm{a}$ \\
OMF 20\% & 139.41 & $118.70 \mathrm{ab}$ & $108.76 \mathrm{ab}$ & $101.41 \mathrm{a}$ & $153.71 \mathrm{~b}$ \\
OMF 30\% & 112.05 & $145.66 \mathrm{~b}$ & $140.76 \mathrm{bc}$ & $139.5^{6} \mathrm{~b}$ & $144.94 \mathrm{~b}$ \\
OMF 50\% & 128.46 & $99.47 \mathrm{a}$ & $98.84 \mathrm{a}$ & $99.35^{\mathrm{a}}$ & $98.52 \mathrm{a}$ \\
p value & 0.206 & 0.012 & 0.000 & 0.000 & $<0.0001$ \\
\hline
\end{tabular}

Legend: Means with the same superscript letters in the same column are not significantly different at $\mathrm{p}<0.05$; OMF: orange maize flour

respectively, and on day 8, an E. coli count of 1.00 $\mathrm{CFU} / \mathrm{g}$ was observed in both the control and $10 \%$ OMF sausages. On day 12, the total plate count increased significantly in almost all sausage formulations, but the highest. E. coli counts were measured in control sausage. However, the results were all within acceptable level of microbiological quality for processed meat, since according to Nel et al. (2004), the maximum limit of E. coli in meat and meat products is $10 \mathrm{CFU} / \mathrm{g}$. The presence of $E$. coli in high numbers indicates the presence of organisms originating from faecal sources ( $\mathrm{Nel}$ et al., 2004). The presence of $S$. aureus can be used as indicator of personal hygiene since the source is usually the skin/hand of food handlers (Mulder, 1996). Also, the lower microbial counts in the OMF sausages could be attributed to the microbial inhibition potential of the OMF due to its total carotene concentration (Arief et al., 2014).

\section{Sensory evaluation of the sausages}

Table 3 shows the mean ratings of sensory attributes for each sausage. There were significant differences $(p<0.05)$ in consumer preference among the sensory parameters assessed except for colour, which showed no significant difference. Consumer preference scores based on texture were the lowest for 50\% OMF sausages as compared to the other sausages, suggesting inclusion of 50\% OMF negatively affected the texture. The consumer preference taste score was higher for control sausage, but this was similar to the taste scores for $10 \%$ and $30 \%$ OMF sausages. The sausage with the most preferred flavour was $10 \%$ OMF sausage. Table 3 shows the mean consumer preference score for overall acceptability was given to sausages with moderate addition of OMF (20\% and 30\% OMF sausages achieved the highest scores).

\section{Conclusions}

In conclusion, the tannin and the phytic acid contents of the OMF were low, while the physicochemical properties of the OMF beef sausages were comparable to those of the control beef sausages. The microbiological results were all satisfactory, showing levels of specific bacteria below the maximum allowable levels for meat and meat products. Thus, OMF can be used to substitute fat in sausages without sausage sensory characteristics being affected.

Disclosure statement: No potential conflict of interest was reported by authors. 


\title{
Uticaj uključivanja brašna narandžastog kukuruza u proizvodnji kobasica od goveđeg mesa i osobine kvaliteta proizvoda
}

\author{
Arthur Vera, Newlove A. Afoakwah
}

A p s tr a kt: Cilj ove studije bio je uključivanje, u različitom procentu $(0 \%, 10 \%, 20 \%, 30 \%$ i 50\%), narandžastog kukuruznog brašna (OMF) u kobasice proizvedene od goveđeg mesa i proučavanje bioaktivnih osobina OMF-a. Takođe, ispitivane su fizičko-hemijske, mikrobiološke i senzorne karakteristike OMF kobasica. Rezultati bioaktivnih analiza OMF-a su pokazali da je ukupan sadržaj karotenoida u OMF bio od 14,31 $\mu \mathrm{g} / \mathrm{g}$, dok je zabeležen sadržaj tanina 1,52 mg/g. Sadržaj vlage u kobasicama smanjio se sa povećanjem udela OMF-a. Sadržaj masti kobasica od goveđeg mesa-OMF bio je značajno niži $(p<0,05)$ u poređenju sa kontrolom, a stabilnost emulzije 30\% OMF kobasice nije se statistički razlikovala od kontrolnih kobasica. Vrednosti joda OMF goveđih kobasica pokazuju trend porasta sa povećanjem koncentracije OMF-a. Salmonella spp. i Staphilococcus aureus nisu otkriveni u kobasicama. Otkrivena Escherichia coli bila je u opsegu od 1,0 do 2,0 CFU/g. Najprihvatljivija OMF goveđa kobasica je bila ona sa 20\% narandžastog kukuruznog brašna. Ova studija je pokazala da narandžasto kukuruzno brašno ima potencijal da se koristi kao zamena za masti, uz očuvanje senzornih svojstava i sprečavanje mikrobnog rasta u goveđim kobasicama.

Ključne reči: narandžasto kukuruzno brašno, bioaktivnost, ukupni karotenoid, jodna vrednost, goveđa kobasica

\section{References}

Afoakwah, N. A., Dong, Y., Zhao, Y., Xiong, Z., Owusu, J., Wang, Y. \& Zhang, J. (2015). Characterization of Jerusalem artichoke (Helianthus tuberosus L.) powder and its application in emulsion-type sausage. LWT - Food Science and Technology, 64, 74-81.

AOAC Association of Official Analytical Chemists. (2006). Official Methods of Analysis. $18^{\text {th }}$ ed., Washington, DC.

Alamu, E. O., Maziya-Dixon, B., Menkir, A. \& Olaofe, O. (2015). Effects of husk and harvesting on provitamin A activity and sensory properties of boiled fresh orange maize hybrids. Journal of Food Quality, 38, 387-395.

Alamu, E. O., Menkir, A., Maziya-Dixon, B. \& Olaofe, 0. (2014). Effect of husk and harvesting time on the carotenoids and acceptability of roasted orange maize hybrids. Food Science and Nutrition, 2, 811-820.

Alvarez, D. \& Barbut, S. (2013). Effect of inulin, b-Glucan and their mixtures on emulsion stability, color and textural parameters of cooked meat batters. Meat Science, 94, 320-327.

Arief, I. I., Suryati, T., Afiyah, D. N. \& Wardhani, D. P. (2014). Physicochemical and organoleptic of beef sausages with teak leaf extract (Tectona grandis) addition as preservative and natural dye. International Food Research Journal, 21, 2033-2042.

Choi, Y. S., Choi, J. H., Han, D. J., Kim, H. Y., Lee, M. A., Kim, H. W., Jeong, J. Y. \& Kim, C. J. (2009). Characteristics of low-fat meat emulsion systems with pork fat replaced by vegetable oils and rice bran fiber. Meat Science, $82,266-271$.

CRA Corn Refiners Association. (2006). Corn oil ( $5^{\text {th }}$ edition.). Washington, DC: Corn Refiners Association.

Gannon, B., Kaliwile, C., Arscot, S. A., Schmaelzle, S., Chileshe, J., Kalungwana, N. \& Tanumiardjo, S. A. (2014). Biofortified orange maize is as efficacious as a vitamin
A supplement in Zambian children even in the presence of high liver reserves of vitamin A: A community-based, randomized placebo-controlled trial. American Journal of Clinical Nutrition, 100, 1541-1550.

Hwang, T., Ndolo, V. U., Katundu, M., Nyirenda, B., Bezner-Kerr, R., Arntfield, S. \& Beta, T. (2015). Provitamin A potential of landrace orange maize variety (Zea mays L.) grown in different geographical locations of central Malawi. Food Chemistry, 196, 1315-1324.

Jitngarmkusol, S., Hongsuwankul, J. \& Tananuwong, K. (2008). Chemical composition, functional properties, and microstructure of defatted macademice flours. Food Chemistry, 110, 23-30.

ISO International Organization for Standardization. (2004). Meat and meat products - Measurement of $\mathrm{pH}$ - Reference method. ISO 2917:2004. Geneva, Switzerland.

Jo, Y. J., Kwon, Y. J., Min, S. G. \& Choi, M. J. (2015). Changes in quality characteristics of pork patties containing multilayered fish oil emulsion during refrigerated storage. Korean Journal of Food Science for Animal Resources, 35, 71-79.

Khan, N., Zaman, R. \& Elahi, M. (1991). Effect of heat treatments on phytic acid content of maize products. Journal of Science Food and Agriculture, 54, 153-156.

Kristinsson, H. G. \& Hultin, H. O. (2003) Role of $\mathrm{pH}$ and ionic strength on water relationships in washed minced chicken breast muscle gels. Journal of Food Science, 68, 917-922.

Lan, O., L., I. \& Lott, J. N. A. (2005). The concentrations and distribution of phytic acid-phosphorus and other mineral nutrients in wild-type and low phytic acid1-1 (lpa1-1) corn (Zea mays L.) grains and grain parts. Canadian Journal of Botany, 83, 131-141. 
Lucia, M. J. C , Patrícia, B. G., Ronoel, L. O. G. , Sidney, P., Pedro, H.F. M., José, L.V. C., Marília R. N., Ana, C. L. N., Ana, C. R. A. V. \& Semíramis, R. R. R. (2012). Total carotenoid content, $\alpha$-carotene and $\beta$-carotene, of landrace pumpkins (Cucurbita moschata Duch): A preliminary study. Food Research International, 47, 337-340.

Mamta K. \& Shashi J. (2015) Screening of potential sources of tannin and its therapeutic application. International Journal of Nutrition and Food Engineering, 9, 7.

Maltin, C., Balcerzak, D., Tilley, R. \& Delday, M. (2003). Determinants of meat quality: Tenderness. Proceedings of the Nutrition Society, 62, 337-347.

McMillan, B., Riggs. D. R., Jackson, B.J., Cunningham, C \& Mcfadden D.W. (2007). Dietary influence on pancreatic cancer growth by catechin and inositol hexaphosphate. Journal of Surgical Research, 141, 115-119.

Méndez-Zamora, G., García-Macías, J. A., Santellano-Estrada, E., Chávez-Martínez, A., Durán-Meléndez, L. A., Silva-Vázquez, R. \& Quintero-Ramos, A. (2015). Fat reduction in the formulation of frankfurter sausages using inulin and pectin. Food Science and Technology, Campinas, 35, 25-31.

Mulder, R. W. A. W. (1996). Biosecurity: Control of pathogenic microorganisms in the poultry industry. Proceedings XXth WPSA World Poultry Congress, Delhi, India, $2,583-588$.

Nawab Khan, R. Z. \& Manzoor, E. (2006). Effect of heat treatment on the phytic acid content of maize products. Journal of the Science of Food and Agriculture, 54, 153-156.

Nel, S., Lues, J. F. R., Buys, E. M. \&Venter, P. (2004). Bacterial populations associated with meat from the deboning room of a high throughput red meat abattoir. Meat Science, 66, 667-674.

Odriozola-Serrano, Hernández-Jover T. \& Martín-Belloso O. (2007). Comparative evaluation of UV-HPLC methods and reducing agents to determine vitamin $\mathrm{C}$ in fruits. Food Chemistry, 105, 1151-1158.

Onomi, S, Okazaki, Y \& Katayama T. (2004). Effect of dietary level of phytic acid on hepatic and serum status in rata feed a high sucrose diet. Bioscience, Biotechnology, and Biochemistry, 68, 1379-1381.

Petersson, K., Godared, O., Eliasson, A. C. \& Tornberg, E. (2014). The effects of cereal additives in low-fat sausages and meatballs, Part 1: Untreated and enzyme-treated rye bran. Meat Science, 96, 423-428.

Palmer, A. C., Chileshe, J., Hall, A. G., Barffour, M. A., Molobeka, N., West, K. P. \& Marjorie, J. H. (2016). Short-term daily consumption of provitamin A carotenoid-biofortified maize has limited impact on breast milk retinol concentrations in Zambian women enrolled in a randomized controlled feeding trial. The Journal of Nutrition, 146, 1783-1792.

Pixley, K., Palacios-Rojas, N., Babu, R., Mutale, R., Surles, R. \& Simpungwe, E. (2013). Biofortification of maize with provitamin A carotenoids. In Tanumihardjo S.,A. (Ed.), Carotenoids and human health New York: Springer Science.

Philip, F., Carlos, A. \& Wallace, A. H. (2002). AOAC International methods committee guidelines for validation of qualitative and quantitative food microbiological official methods of analysis. Journal of AOAC International, 85, 1187-1200.

Rodriguez Furlan, L. T., Padilla, A. P. \& Campderros, M. E. (2014). Development of reduced fat minced meats using inulin and bovine plasma proteins as fat replacers. Meat Science, 96, 762-768.

Shah, T. R., Prasad, K. \& Kumar, P. (2016). Maize - a potential source of human nutrition and health : A review. $\mathrm{Co}-$ gent Food and Agriculture, 54, 1-9.

Shahidi, F. \& Naczk, M. (1995). Food phenolics: Sources, chemistry, effects and applications Lancaster: Technomic Publishing Co. Inc.

Serdaroglu, M. \& Degirmencioglu, O. (2004). Effects of fat level $(5 \%, 10 \%, 20 \%)$ and corn flour $(0 \%, 2 \% 4 \%)$ on some properties of Turkish type meatballs (koefte). Meat Science, 68, 291-296.

Smale, M., Simpungwe, E., Biro, E., Kassie, G. T., de Groote, H. \& Mutale, R. (2015). The changing structure of the maize seed industry in Zambia: Prospects for orange maize. Agribusiness, 31, 132-146.

Tobin, B. D., O'Sullivan, M. G., Hamill, R. M. \& Kerry, J. P. (2012). Effect of varying salt and fat levels on the sensory and physiochemical quality of frankfurters. Meat Science, 92, 659-666.

Ullah, I., Ali, M. \& Farooqi, A. (2010). Chemical and nutritional properties of some maize (Zea mays L.) varieties grown in NWFP, Pakistan. Pakistan Journal of Nutrition, 9, 1113-1117.

WHO World Health Organization. (2009). Global prevalence of vitamin A deficiency in populations at risk 1995-2005. In: WHO Global Database on Vitamin A Deficiency. WHO, Geneva, Switzerland.

Zapata, J. I. H. \& de la Pava, G. C. R. (2018). Physicochemical analysis of frankfurter type sausages made with red tilapia fillet waste (Oreochromis sp) and quinoa flour (Chenopodium quinoa W.). Brazilian Journal of Food Technology, 21, e2016103. 